\title{
SISTEM PENDUKUNG KEPUTUSAN EVALUASI KINERJA MAHASISWA DENGAN METODE PROFILE
}

\author{
Didik Warasto \\ Magister Fakultas Teknik Informatika - UII \\ Jl. Kaliurang Km. 14.5, Kec. Sleman,Daerah Istimewa Yogyakarta 55184 \\ Email : didik_warasto@yahoo.com
}

\begin{abstract}
Abstrak
Untuk melihat sejauh mana kinerja dari mahasiswa yang ada di perguruan tinggi diperlukan sebuah penilaian. Penilaian yang belum terkomputerisasi akan membutuhkan waktu lama, maka dari itu bagaimana membuat sebuah sistem pendukung keputusan yang terkomputerisasi untuk membantu pengambil keputusan dengan baik dan tepat.Aplikasi sistem pendukung keputusan yang akan dibangun adalah sistem pendukung keputusan penilaian kinerja mahasiswa dengan menggunakan metode profile matching. Proses profile matching pada aplikasi menggunakan aspek-aspek yang mengacu pada Tri Dharma Perguruan Tinggi. Proses ini digunakan untuk mencocokkan bobot dari masing-masing kriteria aspek dengan Gap kompetensi. Selanjutnya akan dilakukan proses perhitungan gap antara profil mahasiswa dengan profile tingkat keaktifan studi mahasiswa untuk masing masing sub kriteria kemudian gap-gap tersebut akan di convert ke dalam nilai bobot yang telah ditentukan. Proses selanjutnya adalah menghitung nilai total dari tiap aspek dan dilakukan perangkingan. Sebagai hasil akhir dari proses profile matching adalah perankingan dari mahasiswa yang diproses. Sistem pendukung keputusan ini membantu melakukan penilaian setiap mahasiswa, melakukan perubahan kriteria,dan perubahan nilai bobot. Hasil penilaian berupa perankingan dan dari hasil penilaian dapat diketahui mahasiswa yang berprestasi sehingga layak diberi reward (penghargaan) atau sebaliknya mahasiswa yang kurang berprestasi sehingga diberikan peringatan-peringatan agar kedepannya lebih optimal dalam melaksanakan tugasnya.
\end{abstract}

Kata Kunci : Sistem pendukung keputusan, Gap Kompetensi, Kinerja Mahasiswa

\section{PENDAHULUAN}

Untuk melihat sejauh mana kemampuan dari para mahasiswa dalam proses belajar diperlukan sebuah penilaian terhadap kinerja kepada setiap mahasiswa. Mahasiswa merupakan salah satu komponen dari sebuah perguruan tinggi dengan kewajiban menuntut ilmu. Mahasiswa juga sebagian besar sedang mengalami perubahan menuju pemikiran dewasa, sehingga cenderung masih mencari jatidirinya. Perubahan perilaku dan sikap para mahasiswa dapat mempengaruhi keberhasilan studinya, bahkan dapat digunakan sebagai indikator untuk mengetahui kualitas perguruan tinggi mereka. Perguruan tinggi yang berkualitas mempunyai korelasi yang positif untuk menghasilkan lulusan yang bermutu, hal ini dapat ditandai dengan keaktifan para mahasiswa dalam belajarnya [1].

Menentukan tingkat keaktifan studi mahasiswa tersebut masih dilakukan dengan cara manual dan tanpa menggunakan metode dengan satu indikator saja yaitu dilihat dari hasil belajar yang tanpa melihat proses belajarnya, sehingga sering terjadi kesalahan dalam menentukan mahasiswa yang mempunyai tingkat keaktifan studi yang tertinggi. Bagaimana 
membuat sistem pengambilan keputusan yang dapat membantu pengambil keputusan untuk menentukan tingkat keaktifan studi mahasiswa di Perguruan Tinggi untuk beberapa hal seperti mahasiswa berprestasi, beasiswa, dan studi lanjut[1].

Menurut (Kusrini, 2007) [3] metode profile matching atau pencocokan profil adalah metode yang sering digunakan sebagai mekanisme dalam pengambilan keputusan dengan mengasumsikan bahwa terdapat tingkat variabel prediktor yang ideal yang harus dipenuhi oleh subyek yang diteliti, bukannya tingkat minimal yang harus dipenuhi atau dilewati. Secara hirarkis, Sistem pendukung keputusan (SPK) biasanya dikembangkan untuk pengguna pada tingkatan manajemen menengah dan tertinggi.[4] . Model profile dapat dicocokan sebagai satu set pola gapped dengan kata kunci satuan panjang(Giaquinta, 2014)[5]

SPK dalam sistem informasi dapat dikembangkan jika sistem pengolahan transaksi (level pertama) dan sistem informasi manajemen (level kedua) sudah berjalan dengan baik. Sistem Pendukung Keputusan, didefinisikan juga sebagai sebuah sistem yang mampu memberikan kemampuan, baik kemampuan pemecahan masalah maupun kemampuan pengkomunikasian untuk masalah semi terstruktur.

Salah satu hasil akhir yang diharapkan dapat dicapai dari proses perkuliahan di perguruan tinggi adalah mahasiswa yang mandiri, termasuk mandiri dalam belajar. Mahasiswa diharapkan tidak hanya tergantung pada dosen, dalam arti mahasiswa harus aktif dalam proses belajar. Keaktifan sendiri merupakan motor dalam kegiatan pembelajaran maupun kegiatan belajar, siswa di tuntut untuk selalu aktif memproses dan mengolah hasil belajarnya.

\section{METODE PENELITIAN}

Penelitian ini merupakan penelitian kualitatif dengan rancangan studi kasus, Pendekatan kualitatif digunakan dalam penelitian ini untuk mendeskripsikan bagaimana penggunaan profile matching di perguruan tinggi. Tingkat keaktifan mahasiswa sulit untuk diketahui karena banyak faktor yang mempengaruhinya dan metode khusus yang tepat agar penentuannya menjadi sangat akurat sesuai profil yang sudah ditentukan. Pada penelitian ini akan mencari alternatif yang terbaik yang berdasarkan kompetisi mahasiswa dengan menerapkan metode profile matching.[3] Metode ini dipilih karena mampu menyeleksi alternatif yang terbaik dari aspekaspek kriteria yang ada. Dengan metode profile matching ini akan menghasilkan rangking yang sesuai dan merekomendasikan. Sistem pendukung keputusan tingkat keaktifan studi mahasiswa dengan metode profile Matching ini nantinya akan berbasis dekstop GUI (Graphical User Interface)[2] sehingga akan memudahkan dalam mengakses sehingga dapat membantu pihak bidang akademik dan kemahasiswa dalam pengambilan keputusan. Instrumen penelitian terdiri dari pedoman observasi dan wawancara. Wawancara dilakukan kepada mahasiswa, staf admin dan pembantu direktur bidang akademik dan kemahasiswaan di perguruan tinggi tersebut.

\section{HASIL \& PEMBAHASAN}

\subsection{Proses yang dijalankan}

1. Melakukan perhitungan perbandingan profil mahasiswa yang dinilai untuk mengetahui hasil gap.

2. Melakukan perhitungan nilai bobot dari hasil gap.

3. Melakukan proses perhitungan core dan secondary faktor mahasiswa berdasarkan aspek dari hasil proses penilaian bobot.

4. Melakukan proses perhitungan ranking hasil perhitungan core dan secondary faktor berdasarkan prosentase yang telah dibuat.

\subsection{Data keluaran yang dihasilkan}

Keluaran dari program aplikasi ini adalah berupa laporan data mahasiswa, hasil penilaian. 


\section{Pencocokan Profil (Profile Matching)}

Profile matching atau pencocokan profil adalah metode yang sering digunakan sebagai mekanisme dalam pengambilan keputusan dengan mengasumsikan bahwa terdapat tingkat variabel prediktor yang ideal yang harus dipenuhi oleh subyek yang diteliti, bukannya tingkat minimal yang harus dipenuhi atau dilewati. Contoh penerapanya seperti evaluasi kinerja karyawan untuk promosi jabatan, manajemen football player, penerima beasiswa yang layak. Proses profile matching secara garis besar merupakan proses membandingkan antara nilai data aktual dari suatu profil yang akan dinilai dengan nilai profil yang diharapkan, sehingga dapat diketahui perbedaan kompetensinya (disebut juga Gap), semakin kecil gap yang dihasilkan maka bobot nilainya semakin besar. Berikut adalah beberapa tahapan dan perumusan perhitungan dengan metode profile matching.[3]

Antarmuka perhitungan nilai akhir

Perhitungan profile matching adalah menghitung nilai akhir. Admin menentukan dan memasukkan nilai prosentase dari masing-masing aspek kriteria. dan menekan tombol proses sistem akan menghitung dengan persamaan maka akan didapat nilai akhir.

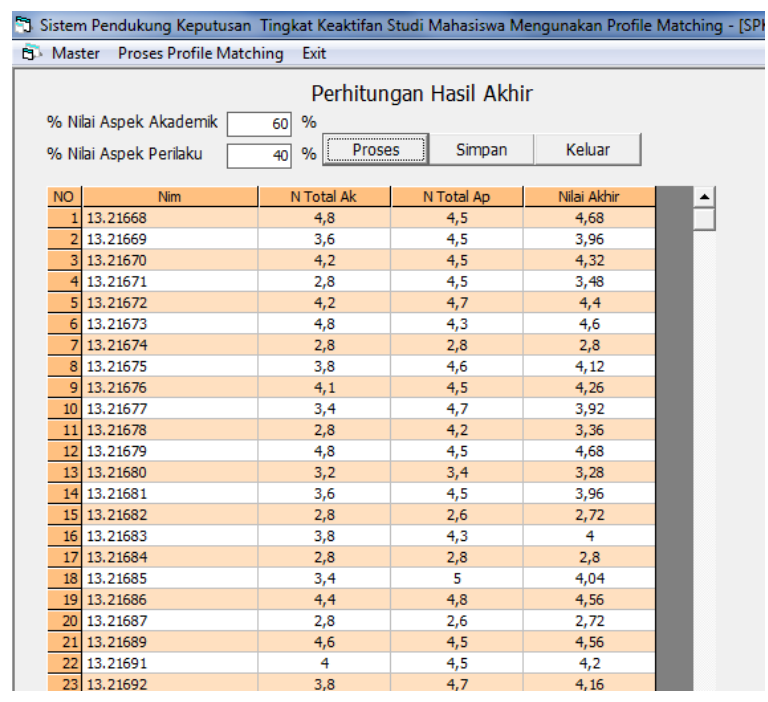

\section{Gambar 1. Tampilan perhitungan nilai akhir}

Grid pada gambar diatas menerangkan bahwa kolom NIM menerangkan Nomor Induk Mahasiswa. Kolom N_Total_Ak menampilkan nilai total dari aspek akademik. Hasil akhir dari proses profile matching adalah rangking berdasarkan tingkat keaktifannya yang tinggi. Antarmuka penampilkan rangking tingkat keaktifan studi mahasiswa. Antarmuka penampilan rangking tingkat keaktifan studi mahasiswa ditumjukkan oleh gambar Gambar 2 dibawah ini : 


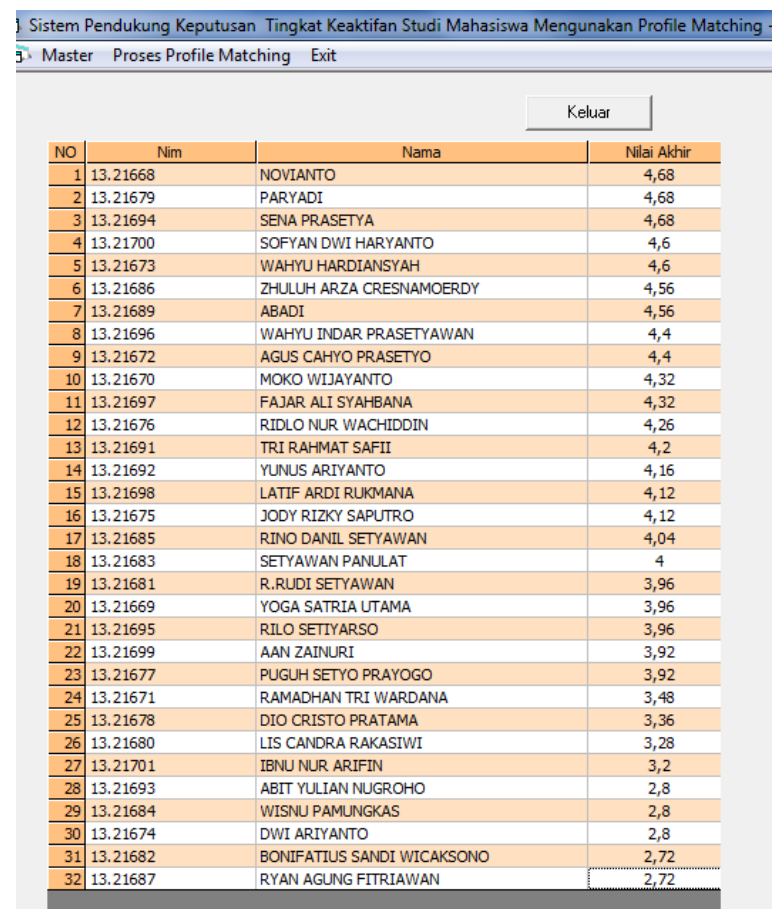

Gambar 2. Laporan penampilkan rangking tingkat keaktifan studi mahasiswa

Pada grid kolom NIM menerangkan nomor induk mahasiswa, kolom nama menerangkan nama mahasiswa dan kolom hasil akhir menerangkan hasil akhir dari perhitungan pada profile matching dan diurutkan berdasarkan nilai akhir.

\subsection{Pembahasan}

Perhitungan-perhitungan dalam proses profile matching akan dijelaskan pada bagian ini yaitu mulai dari proses perhitungan bobot setiap aspek kriteria sampai perhitungan nilai akhir yang digunakan dalam pengambilan keputusan ini. Mulai perhitungan bobot setiap aspek kriteria akan dijelaskan pada sub bab dibawah ini.

\section{Perhitungan Gap Kompetisi}

Setelah proses pemilihan mahasiswa yang akan di nilai, proses selanjutnya menentukan mahasiswa mana yang paling cocok memduduki sebagai mahasiswa yang tingkat keaktifannya tinggi sehingga sebagai yang terpilih. Dalam permasalahan ini penulis mengunakan perhitungan pemetaan gap kompetisi dimana yang dimaksud Gap disini adalah beda antara profil tingkat keaktifan mahasiswa dengan profil mahasiswa atau dapat di tunjukkan dengan persamaan 2.1[3]

$$
\text { Gap }=\text { Profil Mahasiswa }- \text { Profil ideal }
$$

\section{Perhitungan pemetaan Gap}

Komposisi berdasarkan aspek-aspek untuk menentukan perhitungan penentuan mahasiswa dengan dapat mengumpulkan Gap-Gap yang terjadi itu sendiri pada tiap tiap aspeknya yang mempunyai perhitungan yang berbeda beda.

Pada tahap ini, akan ditentukan bobot nilai masing-masing aspek dengan menggunakan bobot nilai yang telah ditentukan bagi masing-masing aspek itu sendiri. Adapun masukan dari proses pembobotan ini adalah selisih dari profil mahasiswa dan profil tingkat keaktifan. Dalam penentuan peringkat pada aspek akademik dan perilaku untuk tingkat 
keaktifan yang sama pada setiap Gap [8], diberikan bobot nilai sesuai dengan tabel.1 berikut :

Tabel 1. Bobot nilai Gap

\begin{tabular}{|c|c|c|l|}
\hline $\begin{array}{c}\text { Gap } \\
\text { No }\end{array}$ & $\begin{array}{c}\text { Selisih } \\
\text { Gap }\end{array}$ & $\begin{array}{l}\text { Bobot } \\
\text { Nilai }\end{array}$ & \multicolumn{1}{|c|}{ Keterangan } \\
\hline 1 & 0 & 5 & Kompetensi sesuai dengan yang dibutuhkan \\
\hline 2 & 1 & 4.5 & Kompetensi individu lebih 1 tingkat/level \\
\hline 3 & -1 & 4 & Kompetensi individu kurang 1 Tingkat/level \\
\hline 4 & 2 & 3.5 & Kompetensi individu lebih 2 Tingkat/level \\
\hline 5 & -2 & 3 & Kompetensi individu kurang 2 Tingkat/level \\
\hline 6 & 3 & 2.5 & Kompetensi individu lebih 3 Tingkat/level \\
\hline 7 & -3 & 2 & Kompetensi individu kurang 3 Tingkat/level \\
\hline 8 & 4 & 1.5 & Kompetensi individu lebih 4 Tingkat/level \\
\hline 9 & -4 & 1 & Kompetensi individu kurang 4 Tingkat/level \\
\hline
\end{tabular}

3. Perhitungan Nilai Total

Dari perhitungan Core Factor dan Secondary Factor dari tiap-tiap aspek, kemudian dihitung nilai total dari tiap-tiap aspek yang diperkirakan berpengaruh pada kinerja tiap-tiap profil. Untuk menghitung nila total dari masing- masing aspek, digunakan persamaan 2.4 (Kusrini, 2007) [3]:

$$
\mathrm{N}=(\mathrm{X}) \% \mathrm{NCI}+(\mathrm{X}) \% \mathrm{NSI}
$$

Nilai total $(\mathrm{N})$ merupakan $(\mathrm{X}) \%$ nilai prosentase yang di inputkan dari NCI yaitu nilai rata-rata Core Factor ditambahkan dengan nilai-nilai prosentase yang di inputkan dari NSI yaitu rata-rata Secondary Factor. Perhitungan nilai total terlebih dahulu menentukan nilai persen yang dimasukkan yaitu Core Factor 60\% dan Secondary Factor 40\%. Kemudian nilai Core Factor dan Secondary Factor ini dijumlahkan sesuai dengan persamaan 2.4.

\section{Perangkingan}

Hasil akhir dari proses profile matching adalah rangking dari kandidat yang di ajukan untuk mengisi jabatan / posisi tertentu. Penentuan mengacu rangking pada hasil perhitungan yang ditentukan oleh persamaan (Kusrini, 2007).[3]

$$
\text { Rangking }=\% \mathrm{NCF}+\% \mathrm{NSF}
$$

NCF mewakili Nilai akhir Aspek akademik dan NSF mewakili Nilai akhir dari Aspek perilaku. 


\section{Implementasi}

Perhitungan-perhitungan dalam proses profile matching akan dijelaskan pada bagian ini yaitu mulai dari proses Perhitungan Bobot Setiap Aspek Kriteria sampai perhitungan nilai akhir yang digunakan dalam pengambilan keputusan. Mulai Perhitungan Bobot Setiap Aspek Kriteria akan dijelaskan dibawah ini.

a. Perhitungan Bobot Setiap Aspek Kriteria

Dari hasil pengambilan basis data untuk subkriteria IPK dan total SKS didapatkan hasil dengan bobot. Setelah memasukkan bobot nilai dari subkriteria presensi dan UKM maka didapat nilai bobot dari setiap aspek.

Tabel 2. Hasil perhitungan bobot nilai sub aspek kriteria

\begin{tabular}{|c|l|l|c|c|c|}
\hline No & NIM & IPK & Total SKS & Presensi & UKM \\
\hline 1 & 13.21668 & 4 & 5 & 5 & 4 \\
\hline 2 & 13.21669 & 2 & 5 & 5 & 4 \\
\hline 3 & 13.21670 & 3 & 5 & 5 & 4 \\
\hline 4 & 13.21671 & 1 & 5 & 5 & 4 \\
\hline
\end{tabular}

Dari hasil perhitungan bobot setiap aspek kriteria dapat di lanjutkan dengan perhitungan pemetaan Gap Kompetesi berikut ini.

b. Perhitungan Pemetaan Gap Kompetisi

Perhitungan pemetaan Gap kompetisi menghasilkan bobot nilai Gap. Bobot nilai Gap setiap subkriteria dapat dilihat pada tabel 3 di bawah ini.

Tabel 3. Tabel Pemetaan Gap Kompetensi

\begin{tabular}{|l|l|l|c|c|c|}
\hline No & NIM & IPK & Total SKS & Presensi & UKM \\
\hline 1 & 13.21668 & 4 & 5 & 5 & 4 \\
\hline 2 & 13.21669 & 2 & 5 & 5 & 4 \\
\hline 3 & 13.21670 & 3 & 5 & 5 & 4 \\
\hline 4 & 13.21671 & 1 & 5 & 5 & 4 \\
\hline \multicolumn{7}{|c|}{ Profil Ideal } & 4 & 5 & 4 & 3 \\
\hline 1 & 13.21668 & 0 & 0 & 1 & 1 \\
\hline 2 & 13.21669 & -2 & 0 & 1 & 1 \\
\hline 3 & 13.21670 & -1 & 0 & 1 & 1 \\
\hline 4 & 13.21671 & -3 & 0 & 1 & 1 \\
\hline \multicolumn{7}{|l|}{ Bobot Nilai Gap } \\
\hline 1 & 13.21668 & 5 & 5 & 4.5 & 4.5 \\
\hline 2 & 13.21669 & 3 & 5 & 4.5 & 4.5 \\
\hline 3 & 13.21670 & 4 & 5 & 4.5 & 4.5 \\
\hline 4 & 13.21671 & 2 & 5 & 4.5 & 4.5 \\
\hline
\end{tabular}

c. Perhitungan Core Factor dan Secondary Factor

Setelah didapatkan nilai bobot Gap dari setiap aspek kriteria langkah berikutnya adalah perhitungan pengelompokan Core Factor dan Secondary Factor. 
Tabel 4. Tabel Pengelompokan aspek akademik

\begin{tabular}{|c|c|c|c|c|c|}
\hline No & NIM & IPK & $\begin{array}{c}\text { Total } \\
\text { SKS }\end{array}$ & Core Factor & $\begin{array}{c}\text { Secondary } \\
\text { Factor }\end{array}$ \\
\hline 1 & 3.21668 & 5 & 5 & 5 & 5 \\
\hline 2 & 3.21669 & 3 & 5 & 3 & 5 \\
\hline 3 & 3.21670 & 4 & 5 & 4 & 5 \\
\hline 4 & 3.21671 & 2 & 5 & 2 & 5 \\
\hline
\end{tabular}

Tabel 5. Tabel Pengelompokan aspek perilaku

\begin{tabular}{|c|c|c|c|c|c|}
\hline No & NIM & Presensi & UKM & Core Factor & Secondary Factor \\
\hline 1 & 13.21668 & 4.5 & 4.5 & 4.5 & 4.5 \\
\hline 2 & 13.21669 & 4.5 & 4.5 & 4.5 & 4.5 \\
\hline 3 & 13.21670 & 4.5 & 4.5 & 4.5 & 4.5 \\
\hline 4 & 13.21671 & 4.5 & 4.5 & 4.5 & 4.5 \\
\hline
\end{tabular}

Perhitungannya sama dengan aspek akademik untuk aspek perilaku adalah sebagai berikut Perhitungan core factor aspek perilaku adalah $\mathrm{NCI}($ perilaku $)=\frac{4.5}{4.5}=$ 4.5. Untuk perhitungan Secondary Factor perhitungannya adalah NSI (perilaku) $=\frac{4.5}{4.5}=$ 4.5. Dalam pengelompokan siapa yang akan menjadi core factor dan secondary factor sangatlah penting dalam metode profile matching ini, yang nantinya akan menjadi penentu dalam perhitungan selanjutnya. Langkah selanjutnya adalah menghitung nilai total setiap aspek kriteria.

\section{d. Perhitungan Nilai Total Aspek Kriteria}

Dari perhitungan core factor dan secondary factor dari tiap-tiap aspek, langkah selanjutnya menghitung nilai total dari tiap-tiap aspek yang diperkirakan berpengaruh pada kinerja tiap-tiap profil. Kemudian nilai core factor dan secondary factor ini dijumlahkan sesuai persamaan tersebut.

Nilai total aspek akademik adalah :

$$
\begin{aligned}
& \text { NIM 13.21668 }=60 \% \times 5+40 \% \times 5=5 \\
& \text { NIM 13.21669 }=60 \% \times 3+40 \% \times 5=3.8 \\
& \text { NIM 13.21670 }=60 \% \times 4+40 \% \times 5=4.4 \\
& \text { NIM 13.21671 }=60 \% \times 2+40 \% \times 5=3.2
\end{aligned}
$$

Nilai total aspek perilaku

NIM $13.21668=60 \% \times 4.5+40 \% \times 4.5=4.5$

NIM $13.21669=60 \% \times 4.5+40 \% \times 4.5=4.5$

NIM $13.21670=60 \% \times 4.5+40 \% \times 4.5=4.5$

NIM $13.21671=60 \% \times 4.5+40 \% \times 4.5=4.5$

Hasil perhitungan ditunjukkan pada tabel 4 dan 5

Tabel 6. Tabel perhitungan Nilai total aspek akademik

\begin{tabular}{|c|c|c|c|c|}
\hline No & NIM & $\begin{array}{c}\text { Core } \\
\text { Factor }\end{array}$ & $\begin{array}{c}\text { Secondary } \\
\text { Factor }\end{array}$ & Nilai Total \\
\hline 1 & 13.21668 & 5 & 5 & 5 \\
\hline 2 & 13.21669 & 3 & 5 & 3.8 \\
\hline 3 & 13.21670 & 4 & 5 & 4.4 \\
\hline 4 & 13.21671 & 2 & 5 & 3.2 \\
\hline
\end{tabular}


Tabel 7. Tabel perhitungan Nilai total aspek Perilaku

\begin{tabular}{|c|c|c|c|c|}
\hline No & NIM & $\begin{array}{c}\text { Core } \\
\text { Factor }\end{array}$ & $\begin{array}{c}\text { Secondary } \\
\text { Factor }\end{array}$ & Nilai Total \\
\hline 1 & 13.21668 & 4,5 & 4,5 & 4,5 \\
\hline 2 & 13.21669 & 4,5 & 4,5 & 4,5 \\
\hline 3 & 13.21670 & 4,5 & 4,5 & 4,5 \\
\hline 4 & 13.21671 & 4,5 & 4,5 & 4,5 \\
\hline
\end{tabular}

Berdasarkan perhitungan yang didapat bahwa sangatlah penting dalam hal memberikan nilai dari prosentase antara core factor dan secondary factor karena akan mempengaruhi hasil perhitungan total tersebut. Jika presentase diubah maka hasilnya akan berubah. Ini adalah salah satu kelebihan dalam metode profile matching dalam sebuah Sistem Pengambilan Keputusan.

e. Perhitungan Nilai Akhir

Perhitungan nilai akhir atau penentuan rangking adalah tahap akhir dari perhitungan dengan metode profile matching. Perhitungan penentuan rangking dihitung dengan hasil penjumlahan dari perkalian input prosentase untuk tiap-tiap kriteria dengan nilai total tiap aspek.

Nilai akhir adalah $\% \mathrm{NCF}+\% \mathrm{NSF}$

NIM $13.21668=60 \% \times 5+40 \% \times 4.5=4.8$

NIM $13.21669=60 \% \times 3.8+40 \% \times 4.5=4.08$

NIM $13.21670=60 \% \times 4.4+40 \% \times 4.5=4.44$

NIM $13.21671=60 \% \times 3.2+40 \% \times 4.5=3.72$

Tabel 8. Tabel perhitungan Nilai Akhir

\begin{tabular}{|l|l|l|l|l|}
\hline No & NIM & $\begin{array}{l}\text { Aspek } \\
\text { Akdemik }\end{array}$ & $\begin{array}{l}\text { Aspek } \\
\text { Perilaku }\end{array}$ & $\begin{array}{l}\text { Nilai } \\
\text { Akhir }\end{array}$ \\
\hline 1 & 13.21668 & 5 & 4,5 & 4,8 \\
\hline 2 & 13.21669 & 3,8 & 4,5 & 4,08 \\
\hline 3 & 13.21670 & 4,4 & 4,5 & 4,44 \\
\hline 4 & 13.21671 & 3,2 & 4,5 & 3,72 \\
\hline
\end{tabular}

Dalam perhitungan hasil akhir ini dipengaruhi berdasarkan penentuan besarnya prosentase yang ditentukan pada prosentase masing-masing aspek kriteria. Ini adalah salah satu kelebihan dalam metode profile matching dalam sebuah Sistem Pengambilan Keputusan. Keluaran yang dihasilkan dari system perangkingan setelah melalui berbagai tahap perhitungan profile matching adalah perangkingan tertinggi ke terendah. Hasil dari perangkingan tertinggi yang akan direkomendasikan oleh sistem sebagai mahasiswa yang tingkat keaktifan studi yang tertinggi. 


\section{KESIMPULAN}

Dari penjelasan dan pembahasan hasil perancangan Sistem Pendukung Keputusan Penilaian Kinerja Mahasiswa di Politeknik Pratama Mulia Surakarta dapat diambil kesimpulan, sebagai berikut:

1. Telah dibuat Sistem Pendukung Keputusan Kinerja Mahasiswa dengan hasil akhir perankingan yang bisa dijadikan alternatif lain bagi kampus untuk membantu dan mempermudah dalam proses pengambilan keputusan serta memberikan solusi atas permasalahan yang dihadapi.

2. Aplikasi sistem pendukung keputusan ini dapat membantu Polteknik untuk mengetahui seberapa besar tingkat prestasi mahasiswa dikampusnya dilihat dari besarnya nilai presentase rangking.

3. Aplikasi ini dapat difungsikan sesuai perancangan dan desain yang telah dibuat, dimana aspek-aspek yang digunakan mengacu pada aspek Tri Dharma.

4. Berdasarkan hasil pembahasan yang telah diuraikan di atas, maka dapat diambil kesimpulan Sistem perangkingan dengan mengunakan metode Profile Matching mampu menghasilkan keputusan yang proposional sesuai dengan aspek kriteria, bobot nilai ideal dan presentase aspek kriteria yang ditentukan.

\section{DAFTAR PUSTAKA}

[1] Sudjana, N. 2010 Penilaian hasil Proses Belajar Mengajar. Bandung: PT Remaja Rosdakarya.

[2] Costa, L. c. 2014 Application of atificial neural networks in history matching process. Petroleum and Engeneering , 1-6.

[3] Kusrini. 2007 Konsep dan Aplikasi Sistem Pendukung Keputusan. Yogyakarta: Andi Offset.

[4] loudon, j. 2010 Mangement Information System Managing The Digital Firm Elevent Edition. New Jersey: Upper Sadle River, Pearson Education, Inc.

[5] Giaquinta, E. e. (2014). Motif matching using patterns. Theoretical Computer Science 548 , $1-13$.

[6] Munawar. 2005 Pemodelan Visual dengan UML, Edisi Pertama. Yogyakarta: Graha Ilmu.

[7] O'Bren, j. 2005 Introduction to Information System, 12th edition. new york: McGraw Hill Companies Inc.

[8] Pizzi, C. U. 2008 Fast Profile Matching Algorithems. Theoritical Computer Science 395 , $137-157$.

[9] Sugiarti, Y. 2013 Analisa dan Perancangan UML Unifified Modelling Language) Generated Vb.6. Yogyakarta: Graha Ilmu. 